\title{
Kinerja Dinas Pemberdayaan Perempuan Dan Perlindungan Anak Kota Pekanbaru
}

\author{
${ }^{1}$ Disya Anggreni Manurung, ${ }^{2}$ Harapan Tua Ricky Freddy Simanjuntak \\ 12 Program Studi Magister Ilmu Administrasi, Universitas Riau \\ email : harapan.tua@lecturer.unri.ac.id
}

\begin{abstract}
Abstrak
Pelaksanaan suatu kegiatan / program kebijakan untuk mewujudkan sasaran , tujuan, misi dan visi dari dinas Pemberdayaan Perempuan dan Perlindungan Anak kota Pekanbaru .Penelitian ini bertujuan untuk mengetahui Kinerja Dinas Pemberdayaan perempuan dan Perlindungan Anak di Kota Pekanbaru dalam menangani kasus kasus dan juga pencegahan terkait tindak kejahatan dan kekerasan yang menimpa perempuan dan juga anak. Upaya - upaya serta program - program yang dibuat untuk melindungi dan mencegah terjadinya tindak kekerasan yang bisa menimpa perempuan dan anak, serta menelaah faktor - faktor penghambat yang terjadi dalam kinerja dinas tersebut . Jenis penelitian ini menggunakan metode kualitatif dengan Pendekatan yang digunakan ialah pendekatan deskriptif yaitu pengamatan dan berdekatana langsung dengan Informan terkait untuk mendapatkan informasi informasi. Hasil penelitian ini menemukan bahwa kinerja dinas pemberdayaan Perempuan dan Perlindungan Anak kota pekanbaru sudah cukup baik, karena dari 5 indikator pengukuran kinerja yang dilakukan peneliti sudah hampir semuanya terpenuhi walaupun belum maksimal. Serta faktor penghambat kinerja yaitu anggapan masyarakat untuk melapor ialah merasa aib, tabu atau hal yang memalukan sehingga lebih baik disimpan sendiri, anggaran yang terbatas dan tidak bisa memenuhi rencana krgiatan dan program - program yang akan dilaksanakan, serta keterbatasan sarana dan prasarana yang ada.
\end{abstract}

Kata Kunci : Kinerja, Pemberdayaan Perempuan dan Perlindungan Anak

\section{Abstract}

The performance of the Pekanbaru City Women Empowerment and Child Protection Service is a description of the implementation of a policy activity / program to realize the goals, objectives, mission and vision of the Pekanbaru City Women Empowerment and Child Protection Service. This study aims to determine the performance of the Women Empowerment and Child Protection Service in Pekanbaru City. Pekanbaru City in handling cases and also prevention related to crimes and violence against women and children. Efforts and programs designed to protect and prevent acts of violence that can befall women and children, and to examine the inhibiting factors that occur in the performance of these offices. This type of research uses qualitative methods with the approach used is a descriptive approach, namely observation and direct proximity to related informants to obtain information. The results of this study found that the performance of the women's empowerment and child protection office of Pekanbaru city was quite good, because of the 5 performance measurement indicators carried out by researchers, almost all of them had been fulfilled although not yet optimal. As well as the inhibiting factor for performance, namely the perception of the public to report being embarrassed, taboo or something embarrassing so it is better to keep it alone, the budget is limited and cannot fulfill the activity plan and programs to be implemented, as well as the limitations of existing facilities and infrastructure.

Keywords: Performance, Women's Empowerment and Child Protection. 


\section{PENDAHULUAN}

Perempuan dan Anak ialah salah satu aspek pentingt bagi negara, karena merupakan tunas bangsa dan generasi penerus, namun keberadaan perempuan dan anak sering kali mengalami keterancaman karena duas aspek penting ini ialah mahluk yang dianggap lemah dan sering menjadi bagian dari orang - orang yang mengalami tindak kejahatan dan kekerasan, untuk itu negara memberikan perlindungan khusus bagi dua aspek penting ini, yaitu dengan memberikan sebuah dinas yang berfungsi untuk menaungi dan menjamin keselamatan dan juga menangani perempuan - perempuan dan anak - anak korban kejahatan dan intimidasi. Dinas ini disebut Dinas Pemberdayaan Perempuan Perlindungan Anak yang dibentuk khusus untuk mengurusi masalah perempuan dan anak, hak - hak serta pengarusatamaan gender.

Dinas Pemberdayaan Perempuan dan Perlindungan Anak ini dibentuk berdasarkan Peraturan Walikota Perkanbaru Nomor 100 Tahun 2016 Tentang Kedudukan, Susunan Organisasi, tugas dan fungsi serta tata kerja dinas Pemberdayaan perempuan dan perlindungan anak Dinas Pemberdayaan Perempuan dan Perlindungan Anak melaksanakan tugas pokok menyelenggarakan urusan pemerintahan bidang pemberdayaan perempuan dan perlindungan anak. Selanjutnya Dinas Pemberdayaan Perempuan dan perlindungan anak kota Pekanbaru juga memiliki fungsi dan tugas yang dibagi menjadi perbidang, bidang Perlindungan Perempuan dan Anak ini memiliki tugas dalam membantu sebagian tugas Kepala Dinas dalam melaksanakan sub urusan perlindungan perempuan dan anak. Dengan tugas dan fungsi sangat jelas tergambar tugas dan fungsi dari bidang perempuan dan anak di dinas PPPA kota Pekanbaru dalam menjamin perlindungan dari kekerasan dan korban kejahatan bagi perempuan dan anak agar terjamin dari kekerasan dan kejahatan yang terjadi baik dalam rumah tangga maupun dari lingkungan luar yang dapat mengancam keamanan.

Kegiatan dalam menjamin keamanan dan kenyamanan perempuan dan anak tersebut adalah bentuk bentuk upaya yang tidak hanya dilakukan pada saat kasus - kasus dan laporan serta aduan - aduan tersebut masuk, namun juga tindakan pencegahan serta kampanye - kampanye yang disuarakan untuk memberikan edukasi dan juga pencegahan terkait tindak kekerasan yang terjadi bagi perempuan dan anak, baik di dalam lingkungan nya sendiri maupun diluar lingkungan rumah nya. Selain itu kegiatan sosialisasi juga penting dilakukan agar masyarakat paham dan juga tidak enggan untuk menyuarakan terkait tindak kekerasan yang dialami baik dalam lingkungan rumah tangganya sendiri maupun diluar. Serta masyarakat paham dan bisa membedakan laporan yang dilakuakan bukan hanya bisa dilaporkan melalui kantor polisi namun juga bisa disuarakan kepada instansi yang menangani khusus terkait urusan perempuan dan juga anak. Namun fakta dilapangan menunjukkan masih kurangnya sosialisasi terkait pemahaman masyarakat terhadap laporan dan aduan terhadap tindak kejahatan yang terjadi pada perempuan dan anak karena angka pelaporan ke kantor polisi lebih tinggi, ini membuktikan bahwa masih banyak masyarakat yang be;lum faham mengenai tugas dan fungsi dari dinas ini, selain itu juga dari data yang ditemukan bahwa angka kejahatan yang di alami oleh perempuan dan anak masih cukup tinggi, terkait laporan dan aduan yang diberikan dalam melayani masyarakat bisa berupa laporan dari orang terdekat juga bisa melalui hotline yang disediakan selama 24 jam, lalu tetap meminta keterangan dari korban yang bersankutan untuk dimintai keterangan.

Dalam penelitian ini membahas mengenai apakah kinerja dinas pemberdayaan perempuan dan perlindungan anak sudah menjalankan tugas dan fungsinya dengan baik dan maksimal sehingga bisa berdampak terhadap angka kekerasan yang dialami oleh perempuan dan anak. 


\section{METODE}

Jenis penelitian ini adalah penelitian kualitatif Jenis penelitian ini adalah kualitatif dengan penddekatan studi kasus yang bersifat deskriptif. bahwa penelitian deskriptif kualitatif adalah meringkas atas fenomena sosial yang terjadi, mencakup nilai, moral, sifat karakter, model dan lain-lain. Dengan metode penelitian ini peneliti dapat mengetahui cara pandang obyek penelitian lebih mendalam, serta melihat pengembangan dalam membentuk suatu variabel dalam penelitian,tentang topic yang dibahas khususnya tentang kekerasan anak dan perempuan. pendekatan ini peneliti dapat emamparkan topic penelitian yang sedang diteliti, mengingat penelitian ini ialah gejala sosial yang terjadi sehingga dengan pengamatan yang peneliti lakukan dapat diamati dengan proses pengamatan dan juga wawancara terhadap informan - informan penelitian yang dituju oleh peneliti.

Informan penelitian yang dipilih meliputi kepala dinas Pemberdayaan Perempuan Perlindungan anak kota pekanbaru , Kasubag bagian kesetaraan gender, Kasubag bagian perlindungan perempuan, Kasubag bagian perlindungan anak, Karyawan dinas PPPA kota Pekanbaru bagian TU, Karyawan Kantor Walikota Pekanbaru bagian Organisasi, Kanit PPA Reskrim Polresta Pekanbaru, Penyidik PPA Polresta Kota Pekanbaru, Korban kekerasan dalam rumah tangga. Tehnik pengumpulan data penelitian menggunakan pengamatan / observasi, wawancara dan dokumentasi. Tehnik analisa data yang digunakan ialah terdiri dari tiga tahapan, yaitu Reduksi data, dengan menajamkan sedemikian rupa sehingga kesimpulan akhir dapat diambil, kedua Penyajian data ketika sekumpulan informasi disusun, sehingga memberi kemungkinan akan adanya penarikan kesimpulan, ketiga Penarikan kesimpulan yaitu penarikan kesimpulan dan verifikasi

\section{HASIL DANPEMBAHASAN}

Kinerja Dinas Pemberdayaan Perempuan dan Perlindungan Anak kota Pekanbaru ialah merupakan upaya - upaya yang dilakukan agar tercapainya perlindungan dan kesejahteraan bagi anak dan perempuan , menjamin segala bentuk perlindungan dan bentuk aduan serta berbagai bentuk pencegahan terkait perlindungan dari tindak kekerasan yang dialami oleh perempuan dan anak. Kinerja dinas yang baik akan membantu mencapai tugas pokok dan fungsi dari tujuan tujuan dinas untuk dapat menciptakan kehidupan yang sejahtera dan terjamin bagi anak dan perempuan yang selalu rentan mengalami tindak kekerasan yang terjadi baik di dalam rumah tangga maupun diluar. Pengukuran Kinerja dinas pemberdayaan Perempuan dan Perlindungan anak kota pekanbaru dilakukan menggunakan indikator pengukuran kinerja Instansi.

1. Pengukuran Kinerja Dinas Pemberdayaan Perempuan dan Perlindungan Anak kota Pekanbaru

a. Produktivitas

Produktivitas adalah ukuran yang menunjukkan kemampuan pemerintah untuk menghasilkan keluaran yang dibutuhkan oleh masyarakat. Kriteria Produktivitas yang baik ialah memiliki program - program berupa program pencegahan dan penanganan yang digunakan sebagai alat dan sarana untuk memperoleh peningkatan kualitas dan juga optimalisasi perlindungan yang diberikan terhadap pengguna pelayanan yaitu anak dan perempuan serta menjamin terlindung dan kenyamanan yang dirasakan.

Dalam mencapai tujuan dari dinas atau suatu instansi sudah barang tentu terdapat beberapa program atau sesuatu yang bisa menjadi senjata untuk bisa sebagai media atau alat dalam mencapai dan membawa instansi atau dinas tersebut dekat dengan tujuan yang akan dicapai, untuk itu sebuah instansi atau dinas yang terdiri dari berbagai bidang bidang harus memiliki sebuah program atau alat media untuk bisa diberikan kepada masyarakat sebagai pengguna pelayanan. Produktivitas ini merujuk pada adanya hubungan antara hasil kerja dengan satuan waktu yang dibutuhkan untuk mencapai target yang diharapkan. Produktivitas yang dihasilkan oleh dinas pemberdayaan 
perempuan dan perlindungan anak guna mencapai tujuan yang diharapkan sudah baik, dimana banyak program program yang sudah berjalan yang dibuat untuk membantu proses mencapai tujuan instansi, anatara lain kegiatan yang dihasilkan ialah Kampanye musical ramah anak, program kota layak huni,sosialisasi kecamatan tentang perempuan dan anak, Puspaga, forum puspa kabupaten, UP2K.

b. Kualitas Layanan

Keberhasilan organisasi publik yang erat kaitannya dengan baik dan memuaskan sesuai dengan harapan konsumen atau pengguna layanan. Terkait dalam memberikan pelayanan dan bantuan kepada masyarakat yang membutuhkan pelayanan dan bimbingan terhadap kebutuhan untuk mendapatkan pelayanan yang maksimal dan puas. Terdapat beberapa kriteria yang menunjukkan kualitas layanan yang baik seperti meminimalkan kesalahan dalam pelayanan maupun transaksi, sopan santun dan kemudahan memberikan pelayanan, konsumen dan fasilitas pendukung, kenyamanan konsumen, lokasi tempat parkir, ruang tunggu yang nyaman, ketersediaan informasi. Maka seharusnya dalam pelayanan terdapat kaidah yaitu kemudahan kemudahan yang diberikan untuk pengguna layanan. Kemudahan layanan yang diberikan oleh dinas pemberdayaan perempuan dan perlindungan anak kota Pekanbaru sudah baik, dimana dalam melakukan pelayanan sangat dimudahkan dan dibantu,seperti tersedianya PATBM yaitu Perlindungan anak terpadu berbasis masyarakat, merupakan sarana yang disediakan berupa orang - orang yang bersedia sebagai cctv untuk membantu melaporkan kejahatan yang terjadi di masing-masing kelurahan dalam memberikan laporan terkait adanya tindak kekerasan yang mungkin terjadi di lingkungan sekitar dan bisa melaporkannya, selain itu dalam penyelesaian kasus yang masuk pihak Upt PPA menyediakan kemudahan dalam memberikan bantuan berupa bantuan hukum, konselor, maupun psikologi dan juga layanan yang dapat dijangkau sewaktu - waktu korban tidak bisa dating ke kantor, serta kemudahan - kemudahan lainnya seperti ruang yang nyaman untuk bercerita.

\section{c. Responsivitas}

Kemampuan pemerintah untuk mengenali kebutuhan masyarakat, menyusun agenda dan prioritas pelayanan, serta mengembangkan program-program pelayanan sesuai dengan kebutuhan dan aspirasi masyarakat. Secara singkat, dapat dikatakan bahwa responsivitas mengukur daya tanggap pemerintah terhadap harapan, keinginan dan aspirasi, serta tuntutan kostumer.

Responsivitas yang diterima oleh dinas kurang baik ,dimana keterbatasan anggaran yang dihadapi dan beberapa tuntutan - tuntutan tidak berjalan dengan sesuai yang dimau akibat dari rapat assessment yang tidak dilibatkan oleh pihak pusat membuat kebutuhan - kebutuhan yang sebenarnya tidak tersalurkan dengan baik. Dengan kurangnya kordinasi dengan pusat menjadikan anggaran yang diterima juga terbatas dalam memenuhi sarana dan prasarana yang dibutuhkan seperti penyediaan rumah aman yang sejatinya sangat butuh untuk diadakan karena merupakan sarana prasarana yang primer dan mendesak untuk di adakan, serta beberapa program lainnya yang terpaksa ditiadakan akibat pengalihan fungsi anggaran.

\section{d. Responsibilitas}

Responsibilitas merupakan suatu ukuran yang menunjukkan seberapa jauh pemberian pelayanan publik itu dilakukan sesuai dengan prinsip-prinsip atau ketentuan-ketentuan administrasi dan organisasi yang benar dan telah ditetapkan. Kriteria responsibilitas yang baik ialah efektif, tidak berbelit-belit atau sederhana dalam alur pelayanan, kejelasan dan kepastian (transparant), keterbukaan, dicegah adanya pemenuhan persyaratan, menyesuaikan yang menjadi tuntutan, ketepatan waktu. 
Pelayanan yang berbelit - belit dan prosedur yang tidak beraturan serta syarat - syarat yang tidak karuan merupakan tindakan pelayanan yang tidak responsibilitas, sebaliknya dengan adanya acuan dan langkah - langkah pelayanan yang terarah dan terstruktur dan berprosedur dengan baik menjadikan pelayanan yang diberikan lebih mudah dan lancar. Pelayanan yang diberikan oleh dinas pemberdayaan perempuan dan perlindungan anak ini haruslah yang sesuai dan segampang mungkin, karena terkadang masalah - masalah dan pengaduan - pengaduan yang masuk sangat mendesak untuk ditangani secepat mungkin dan semudah mungkin, jangan sampai pelapor menjadi sulit dan terbebani dalam menyampaikan keluhan dan masalah yang dihadapi. Namun dari hasil yang penelitian yang dilakukan responsibilitas pelayanan sudah baik, dimana hotline 24 jam disediakan untuk menangaapi aduan dan keluhan yang masuk, serta mendesak untuk ditangani. Selain itu tindak lanjut untuk menanggapi aduan dan pertolongan juga disederhanakan sebisa mungkin untuk merespon aduan dan keluhan yang masuk.

\section{e. Akuntabilitas}

Kewajiban untuk memberikan pertanggungjawaban atau menjawab dan menerangkan kinerja dan tindakan seseorang atau organisasi kepada pihak yang memiliki hak atau berkewenangan untuk meminta keterangan atau pertanggungjawaban.

Akuntabilitas dari dinas ini juga dilaporkan dan dinilai langsung kepada walikota dengan berupa survey yang dibuat dan diadakan oleh walikota untuk menilai hasil kepuasan masyarakat terkait pelayana yang diberikan oleh dinas terkait dalam menyelesaikan tugas dan fungsi yang sudah ditetapkan dan menjadi tanggungjawab dinas terkait. Berdasarkan hasil survey kepuasan yang diberikan oleh dinas terkait dengan survey yang berpedoman terhadap kementrian PAN-RB yang dilakukan oleh Walikota Pekanbaru terhadap kriteria kriteria pengukuran yang diberikan. Hasil dari IKM (indeks kepuasan masyarakat dinas pemberdayaan perempuan dan perlindungan anak Kota Pekanbaru tahun 2019 ialah 81,77 dengan nilai B.

2. Faktor penghambat kinerja dinas pemberdayaan perempuan dan perlindungan anak kota Pekanbaru

a. Keterbatasan Anggaran

Segala bentuk pencegahan maupun pelayanan yang diberikan umumnya merupakan program - program yang dibuat untuk menghasilkan sesuatu baik upaya untuk meningkatkan kualitas maupun upaya pencegahan yang diberikan oleh dinas untuk memberikan kesejahteraan dan rasa aman bagi anak dan perempuan untuk bisa merasa aman dan nyaman serta terjaga dari bahaya tindak kejahatan yang mungkin menimpanya. Untuk itu program - program dibuat untuk upaya dalam sosialisasi dalam bentuk pencegahan maupun untuk meningkatkan kualitas pelayanan yang diberikan, barang tentu program - program aatau kegiatan tersebut merupakan kegiatan yang membutuhkan biaya - biaya, karena umumnya merupakan program - program yang diberikan untuk mengumpulkan orang banyak, belum lagi sarana dan prasarana yang dibutuhkan selama kegiatan itu, seperti alat tulis, makanan dan lainnya. Beberapa kegiatan yang mengumpulkan banyak orang tentu tidak dengan biaya yang sedikit, untuk itu maka beberapa kegiatan terpaksa ditiadakan karena keterbatasan anggaran yang ada. Alokasi dana APBD Pemerintah Kota Pekanbaru untuk Dinas Pemberdayaan Perempuan dan Perlindungan Anak dirasa masih perlu untuk ditingkatkan guna menunjang kualitas pelayanan yang lebih baik, contohnya bisa memberikan layanan yang lebih lengkap sarana dan prasarananya contohnya ialah sarana prasarana rumah aman, mobil aman, dll. 
b. Masyarakat masih merasa tabu / malu untuk melaporkan ketika terjadinya kasus kekerasan.

Kasus kekerasan yang terjadi terkadang bukan hanya menimbulkan beban fisik yang mendalam , namun juga beban bagi keluarga dan luka yang mendalam untuk orang terdekat yang mengalami kekerasan atau kejahatan, apalagi judge dari tetangga yang menimbulkan perasaan tidak enak untuk keluarga, yang menimbulkan beberapa orang untuk tidak ingin melaporkan dan justru menutupi masalah yang dihadapi, daripada menghadapi gunjingan orang terdekat atau tetangga.

c. Sarana dan prasarana

Keterbatasan anggaran yang dihadapi oleh dinas membuat dinas tidak berdaya untuk mencukupi kebutuhan yang diperlukan oleh dinas seperti beberapa aspek vital seperti rumah aman, yang belum bisa terlaksana dan terpenuhi, yang sejatinya merupakan objek yang penting dalam memberikan pelayanan yang mumpuni. Hal ini memberikan hambatan tersendiri dan memberikan keterbatasan untuk bisa lebih memberikan pelayanan yang optimal.

\section{KESIMPULAN}

1) Dari hasil penelitian yang dilakukan oleh peneliti terkait kinerja dinas pemberdayaan perempuan perlindungan anak kota Pekanbaru dalam menangani kekerasan terhadap perempuan dan anak di kota Pekanbaru kinerja yang dihasilkan terkait penelitian serta berbagai wawancara yang peneliti lakukan kinerja yang diberikan terkait pemenuhan tugas tugas serta fungsi - fungsi yang dilakukan serta upaya - upaya yang dihadapi sudah cukup baik dan membantu dalam memberikan pelayanan dan menanggapi aduan - aduan yang masuk dan berkembang di masyarakat, namun dalam beberapa aspek masih kurang maksimal karena masih ditemukannya beberapa yang belum optimal pelayanan dalam menyelenggarakan tugas pokok dan fungsi dari dinas DPPPA kota Pekanbaru ini, seperti pelayanan psikologi yang hanya dijadikan opsi ataupun penyelesaian pembantu dari penanganan kasus yang ada, sehingga jika dirasa penanganan kasus yang dilakukan tidak membutuhkan bantuan psikologi dalam tahap penyidikan masalah dan perkara, dan korban yang mengalami bisa dipertanyakan secara bahasa lisan maka tindakan penanganan oleh psikologi dianggap tidak perlu dilakukan, sehingga aspek psikologi disini lebih mendukung atas penyelesaian kasus yang ditangani dan membantu dalam memberikan keterangan kalau - kalau korban yang mengalami kekerasan tersebut masih anak dibawah umur yang sulit ditanyai dan memberikan keterangan, bukan sebagai suatu hal yang wajib yang perlu ditekankan sebagai salah satu aspek penting untuk menyelesaikan kasus dan juga masalah psikologi yang dialami oleh korban.

Selanjutnya sosialisasi yang diberikan oleh dinas Pemberdayaan Perempuan dan Perlindungan anak kota Pekanbaru dalam memberikan layanan dan pengetahuan kepada masyarakat awam masih kurang dan tidak menjangkau dengan rata, tidak menyeluruh dalam memberikan edukasi terkait pengetahuan dan edukasi dasar untuk tindak pencegahan yang bisa dijadikan tindakan preventif, selain itu pentingnya sosialisasi tentang dinas ini juga bisa mencegah orang - orang untuk langsung melapor kepada polisi, namun bisa diselesaikan dengan cara mediasi di dinas terkait.

Penilaian kinerja yang dilakukan oleh Walikota mengacu kepada peraturan MEN PANRB terkait pelayanan yang diberikan dinas PPPA kota Pekanbaru terkait pelayanan yang diberikan kepada konsumen, yaitu Layanan pemulihan psikologi Perempuan dan Anak korban kekerasan, Layanan pendampingan Hukum untuk perempuan dan anak sebagai korban dan bagi anak yang berhadapan dengan hukum, Layanan penyelesaian konflik yang melibatkan perempuan dan anak di luar pengadilan (Mediasi), melibatkan Sembilan unsur penilaian yaitu, persyaratan pelayanan, sistem, mekanisme, dan prosedur, waktu penyelesaian, biaya / tarif, Produk spesifikasi jenis 
pelayanan, kompetensi pelaksana, sarana dan prasarana, penaganan pengaduan,saran dan masukan terdapat nilai dengan dua mutu $\mathrm{A}$, dan tujuh penilaian dengan nilai mutu $\mathrm{B}$, dengan IKM sebesar 81,77 dengan indeks nilai mutu hasil yaitu $\mathrm{B}$.

2) Hambatan yang ditemukan dari pengembangan Pelayanan Dinas Pemberdayaan Perempuan dan Perlindungan Anak kota Pekanbaru :

Masyarakat merasa tabu untuk melaporkan terjadinya kasus kekerasan, Alokasi dana APBD Pemerintah Kota Pekanbaru untuk Dinas Pemberdayaan Perempuan dan Perlindungan Anak dirasa masih perlu untuk ditingkatkan, Keterbatansan anggaran yang diberikan membuat banyak kegiatan yang dicanangkan tidak bisa berjalan atau terpaksa harus ditiadakan untuk kepentingan pendanaan yang lain, Kurangnya perhatian terkait sarana dan prasanarana terhadap PATBM Perlindungan anak terpadu berbasis masyarakat, padahal PATBM tersebut sangat dibutuhkan sebagai cctv dalam melaporkan hal - hal yang terjadi disekitar wilayah dimana PATBM tersebut berada, Keterbatasan dana untuk melengkapi sarana prasarana yang dibutuhkan misalnya rumah aman yang menjadi kebutuhan sarana utama untuk menjamin keamanan korban yang mengalami tindak kekerasan dan melapor ke dinas terkait.

\section{SARAN}

Adapun saran - saran yang dapat peneliti berikan agar menjadi masukan dalam menanggapi kinerja dinas Permberdayaan Perempuan dan Perlindungan Anak Kota Pekanbaru adalah sebagai berikut:

1) Saran yang peneliti lakukan terkait kinerja dari dinas Pemberdayaan Perempuan dan Perlindungan Anak kota Pekanbaru, untuk mendapatkan kinerja yang baik dibutuhkan kesungguhan dan kerjasama yang baik, serta juga memberikan upaya yang maksimal dalam melakukan dan menangani pelayanan yang diberikan, layanan yang professional dan konsisten selalu memberikan yang terbaik untuk menyelesaikan kasus - kasus dan pengaduan yang masuk, namun juga bukan hanya itu saja, dinas Pemberdayaan perempuan dan Perlindungan Anak juga memiliki kewajiban dalam hal sosialisasi dan mengkampanyekan hal - hal terkait perlindungan anak dan perempuan, dan bertanggungjawab terhadap pencegahan yang mengakibatkan kekerasan terhadap perempuan dan anak, serta bisa memaksimalkan pelayanan dengan sarana dan prasarana yang lengkap dan nyaman serta ramah, dan memberikan bisa menyadari bahwasannya tanggungjawab dari dinas ini bukan hanya menyelesaikan kasus dan aduan - aduan yang masuk, namun juga mempersiapkan dan menggalakkan kegiatan - kegiatan pencegahan yang bisa meminimalisir tindak dan tanduk kejahatan yang menimpa anak dan perempuan, serta memperkenalkan kepada seluruh masyarakat bahwa gender itu harus ditegakkan, dan bisa berpengaruh luas dari sekedar apa yang mereka bayangkan dan fikirkan.

2) Upaya meminimalisir hambatan hambatan yang ditemukan, maka harus adanya kordinasi yang baik termasuk anggaran yang nanti akan dianggarkan dari hasil rapat assessment yang dilakukan. Selanjutnya memaksimalkan sosialisasi yang diberikan kepada masyarakat untuk lebih mengerti dan memahami fungsi dari dinas ini, agar jangan sampai masyarakat justru mengadu kepada kantor polisi untuk hal hal terkait perempaun dan anak yang harusnya bisa diupayakan dengan baik, selanjutnya lagi dalam hal penanganan korban yang mengalami trauma atau korban yang dewasa atauapun korban yang masih dalam usia anak - anak, baiknya menurut pandangan peneliti penanganan kasus tidak hanya berfokus kepada penyelesaian kasus saja, namun juga aspek psikologi dan trauma healing dari korban, agar korban bisa menjadi lebih percaya diri lagi dalam melanjutkan kehidupan kedepannya, jika perlu diberikan kegiatan pra kasus untuk meningkatkan keahlian dan 
mengisi waktu kegiatan yang lebih bermanfaat dan bisa menghasilkan daya ekonomi, Selanjutnya bisa mengupayakan dan lebih memperhatikan lagi PATBM tersebut agar bisa lebih maksimal dalam proses pengamatan di berbagai kecamatan dan kelurahan diseluruh kota Pekanbaru karena PATBM tersebut sangat dibutuhkan sebagai cctv dalam melaporkan hal - hal yang terjadi disekitar wilayah dimana PATBM tersebut berada, selanjutnya untuk mengupayakan rumah aman yang sangat dibutuhkan bagi korban, peneliti menyarankan untuk dinas PPPA kota Pekanbaru mengupayakan dengan cara lain , seperti penyewaan rumah sementara yang bisa digunakan untuk melindungi korban yang mungkin tidak aman untuk kebali kerumah karena mungkin orang terdekat yang menjadi penyebab terjadinya kekerasan. Semoga dinas pemberdayaan perempuan perlindungan anak kota Pekanbaru lebih maksimal lagi dalam memberikan pelayanan yang optimal untuk masyarakat.

\section{DAFTAR PUSTAKA}

[1]. Adam, Indrawijaya. (2000). Perilaku Organisasi. Bandung: Sinar Biru Aglesindo.

[2]. Amsyah, Zulfikri,2003 Manajemen Kearsipan, Jakarta: Penerbit PT Gramedia Pustaka Utama.

[3]. Abdul, Ghafur Anshori, Perbankan Syariah Di Indonesia, Yogyakarta: Gadjah Mada University Press,2009 hal 13

[4]. Armstrong,Michael. Performance Management $4^{\text {th }}$ edition 2009. London: N1 9JN page 122, 124.

[5]. Anwar, A.A Prabu Mangkunegara,2009. Manajemen Sumber Daya Manusia Perusahaan Depok: Rosda Pustaka hal 9.

[6]. Boedi, Abdullah oleh Mukarom.Zaenal dan Wijaya Laksana,Muhibin. 2015. Membangun Kinerja Pelayananan Publik Menuju Clean Government and Good Governance. Bandung: Pustaka Setia.

[7]. Bagong, Suyanto dan Sutinah. 2011. Metode penelitian Sosial Berbagai Alternatif.Pendekatan. Jakarta: Prenada Media Grup.

[8]. Al Fajar, Siti,. Tri Heru.April,2010. Manajemen Sumber Daya Manusia sebagai dasar meraih keunggulan bersaing. Yogyakarta: Sekolah Tinggi Ilmu Manajemen YKPN hal 148.

[9]. Dwiyanto, Agus.2005. Mewujudkaan Good Goovernance Melalui Pelayanan Publik Yogyakarta: Gadjah Mada University Press.

[10]. Eddyono,W. Supriyadi. 2005. Pengantar Konvensi Hak Anak, ELSAM, Jakarta : Karyawan.Penerjemah Ramlan. PPM.

[11]. Foster, Bill \& Seeker, Karen R. 2001. Pembinaan untuk Meningkatkan Kinerja Karyawan. Jakarta: Penerjamahan Ramlan. PPM.

[12]. Fattah,Nanang. 2016. Sistem Penjamin Mutu Pendidikan. Bandung: PT Remaja Rosdakarya Persada hal 19. 
[13]. Pasolong, Harbani.2008. Teori Administrasi Publik .Bandung: Alfa Beta hal ;176.

[14]. Mukarom,Zaenal. Wijaya, Muhibin Laksana, 01 Februari 2016. Membangun Kinerja Pelayanan Publik. Bandung: Pustaka Setia Bandung hal 67-68, 126.

[15]. Munandar, M Sulaeman, Siti Homzah. ekerasan terhadap Perempuan. April 2019. Bandung: Refika Aditama hal 85, 88 .

[16]. Simanjuntak, J Payaman. Manajemen dan Evaluasi Kinerja. Jakarta: Lembaga Penerbit Fakultas Ekonomi Universitas Indonesia hal 20-21, 3.

[17]. Handayaningrat, Soewarno. 1985. Pengantar Ilmu Administrasi Dan Manajemen. Jakarta: Haji Masagung.

[18]. R Jhon, Schermerhorn Jr. 1994 dalam Tesis Eka Juliana,Universitas Riau 2011.

[19]. Mathis, Robert L. dan Jackson. John H. 2006. Human Resource Management(Manajemen Sumber Daya Manusia)Edisi 10. Jakarta: Salemba Empat.

[20]. Marwansyah 2010. Manajemen Sumber Daya Manusia. Bandung: Alfabeta hal 229-230.

[21]. Parasuraman et al. Responsibilitas dalam Zeinthaml dan Bitner 1996 hal 118.

[22]. Ruky, Ahmad. 2004. Sistem Manajemen Kinerja. Jakarta: Gramedia Utama

[23]. Revianto. 2014:11. Pengertian Efektivitas dalam dosenpendidikan.co.id diakses 04-02-2020

[24]. Suprihanto, John. 2004. Perilaku Organisasional. Yogyakarta: STIE YKPN hal 77.

[25]. Steers, Richard M. 1985. Efektivitas Organisasi, Erlangga. Jakarta: Stoner, James, A.F., 1986. Alih Bahasa : Gunawan Hutauruk, Manajemen Jilid II, Erlangga, Jakarta.

[26]. Wibowo. 2013: 7 dalam Pemahaman Manajemen Sumber Daya Manusia Strategi mengeloola karyawan oleh Arif Yusuf Hamali, CAPS(Center for Academic Publishing Service) 2016.

[27]. Wirawan (2012;7-8) dalam Pemahaman Manajemen Sumber Daya Manusia Strategi mengeloola karyawan oleh Arif Yusuf Hamali, CAPS(Center for Academic Publishing Service)2016 hal 7, 11, 99.

[28]. Wibowo. 2015. Perilaku Dalam Organisasi edisi ke 2. Jakarta: Rajawali Pers.hal.78.

[29]. Zeithaml,loc.cit., hal 29 (1990) dalam Dr. H. Zaenal Mukarom, M.Si Muhibudin Wijaya Laksana. hal 126 